Eur. J. Clin. Chem. Clin. Biochem.

Vol. 31,1993 , pp. $651-656$

(C) 1993 Walter de Gruyter \& Co.

Berlin - New York

\title{
Granulocyte Chemotaxis Measured in a Boyden Chamber Assay by Quantification of Neutrophil Elastase
}

\author{
By G. Pelz, Almut Schettler and H. Tschesche \\ Lehrstuhl für Biochemie, Fakultät für Chemic, Universität Bielefeld, Bielefeld, Germany
}

(Received April 5/July 19, 1993)

Summary: The human polymorphonuclear leukocyte reaction in response to chemotactic or chemokinetic stimulation is often assayed using the Boyden chamber technique. We present a quick and reliable method for evaluating Boyden chamber experiments, which avoids time-consuming cell counting and does not require expensive equipment. This method is based on assaying human neutrophil elastase, a serine protease derived from polymorphonuclear leukocytes. We tested the method in different types of Boyden chambers equipped with two superimposed filters or a filter amnion membrane combination. The chambers were incubated with the cells for $2 \mathrm{~h}$ then dismantled and the elastase activity in supernatant, filters or membrane was assayed. The results were compared with the results obtained by cell counting, or measured by determination of myeloperoxidase. There was a good correlation between the cell count and elastase technique $(r=0.90)$, but the elastase method achieved higher intra- and interassay precision. Myeloperoxidase and elastase results also correlated well $(r=0.94)$ and showed comparable intra- and inter-assay precision. With the elastase method it was also possible to quantify polymorphonuclear leukocyte reactions on an amnion membrane surface. In amnion membrane assays the percentage of cells which reacted in response to formyl-peptide stimulation was not altered by varied cell concentrations, and polymorphonuclear leukocytes showed little unstimulated adherence or migration.

\section{Introduction}

Polymorphonuclear leukocytes are the primary effector cells at sites of acute inflammatory processes. Their ability to follow gradients of chemotactic reagents and migrate through vesșel walls and tissue barriers is essential for their function in the host defence system. Several in vitro methods for detecting chemotactic activity of polymorphonuclear leukocytes have been developed, including the so-called Boyden chamber invented by Boyden in 1962 (1). The Boyden chamber consists of two (upper and lower) compartments separated by a microporous filter membrane. When a chemotactic substance is placed in the lower, and the cells are placed in the upper compartment of the chamber, polymorphonuclear leukocytes migrate into the filter along the resulting concentration gradient. The method mainly used to measure the chemotactic response is the cell counting technique. The distance which the cells travel into the filter (leadingfront technique) can be determined after fixation and staining. Alternatively the number of cells which migrate a given distance into the filter is counted. Several other methods have been recommended to avoid timeconsuming microscopic counting of the cells (for review see 1.c. (2)). Gallin et al. (3) described a method in which cells were labelled with the radioactive tracer ${ }^{51} \mathrm{Cr}$. Two overlayed filters were used. The number of polymorphonuclear leukocytes which penetrated through the first filter was determined by measuring the radioactivity of the lower filter. Somersalo et al. (4) invented a method also using two filters, and measuring the content of human polymorphonuclear leukocyte myeloperoxidase ${ }^{1}$ ) in the lower filter. This method avoided working with radioactive isotopes and was easier to perform than cell-counting techniques. 
We have developed a method similar to Somersalo's based on quantifying human polymorphonuclear leukocyte elastase ${ }^{1}$ ). Human polymorphonuclear leukocyte elastase is easier to handle and to measure than myeloperoxidase, which makes elastase assays suitable for routine use. Moreover, elastase and myeloperoxidase assays may complement one another when experimental conditions do not permit the use of the myeloperoxidase method.

\section{Materials and Methods}

\section{Isolation of polymorphonuclear leukocytes}

Fresh blood was taken by venipuncture from healthy volunteers. Polymorphonuclear leukocytes were isolated from the heparinized blood according to the method of Boyum (5). Polymorphonuclear leukocytes were separated from the blood by sedimentation in a mixture of Ultravist/Methocel $(18.2 \mathrm{ml} /$ $100 \mathrm{ml}$ Ultravist, Schering, Berlin; $1.45 \mathrm{ml} / 100 \mathrm{ml}$ Methocel, Sigma, München), followed by density gradient centrifugation with Histopaque-1077 (Sigma, München). Some remaining erythrocytes were removed by hypotonic lysis, and the polymorphonuclear leukocytes resuspended in a buffer solution containing $140 \mathrm{mmol} / \mathrm{l} \mathrm{NaCl}, 2.7 \mathrm{mmol} / \mathrm{l} \mathrm{KCl}, 8 \mathrm{mmol} / \mathrm{l}$ $\mathrm{Na}_{2} \mathrm{HPO}_{4} \cdot 2 \mathrm{H}_{2} \mathrm{O}, 1.5 \mathrm{mmol} / \mathrm{l} \mathrm{K} \mathrm{PO}_{4}(\mathrm{pH} 7.3), 0.5 \mathrm{mmol} / \mathrm{l}$ $\mathrm{MgCl}_{2} \cdot 6 \mathrm{H}_{2} \mathrm{O}, 0.9 \mathrm{mmol} / \mathrm{l} \mathrm{CaCl}{ }_{2} \cdot \mathrm{H}_{2} \mathrm{O}, 1 \mathrm{~g} / \mathrm{l}$ glucose and 10 $\mathrm{g} / \mathrm{l}$ human serum albumin (Institut Mérieux $\mathrm{GmbH}$, Leimen). Viability of the polymorphonuclear leukocytes was $>95 \%$ as determined by exclusion of trypan blue.

\section{Human amnion membrane}

Normal term placentas were obtained from the hospital immediately after delivery and stored in phosphate-buffered saline containing penicillin and streptomycin $\left(100 \times 10^{3} \mathrm{IU} / \mathrm{l}\right.$ and 10 $\mathrm{mg} / \mathrm{l}$, respectively; Sigma, München). The adherent chorion was peeled away from the amnion, and the epithelial cell layer was scraped off after treatment with $40 \mathrm{~g} / \mathrm{l}$ deoxycholate solution for $30 \mathrm{~min}$ (Sigma, München). The remaining basement membrane was washed carefully with the buffer solution used for resuspending polymorphonuclear leukocytes (see above).

\section{Boyden chamber preparation}

Chemotaxis chambers similar to that described by Russo et al. (6) were used. The two parts of the chemotaxis chamber were separated either by one $5 \mu \mathrm{m}$ micropore filter (Millipore S. A., Molsheim), a two filter combination with one upper $5 \mu \mathrm{m}$ or $8 \mu \mathrm{m}$ filter and one lower $0.22 \mu \mathrm{m}$ filter, or a human amnion membrane and an underlying $0.22 \mu \mathrm{m}$ filter. Filters were soaked with buffer $\mathrm{A}$ containing $140 \mathrm{mmol} / \mathrm{l} \mathrm{NaCl}, 2.7 \mathrm{mmol} / \mathrm{K} \mathrm{KCl}, 8$ $\mathrm{mmol} / 1 \mathrm{Na}_{2} \mathrm{HPO}_{4} \cdot 2 \mathrm{H}_{2} \mathrm{O}, 1.5 \mathrm{mmol} / 1 \mathrm{~K}_{2} \mathrm{HPO}_{4}, 0.5 \mathrm{mmol} / \mathrm{l}$ $\mathrm{MgCl}_{2} \cdot 6 \mathrm{H}_{2} \mathrm{O}, 0.9 \mathrm{mmol} / \mathrm{l} \mathrm{CaCl} \mathrm{Cl}_{2} \cdot \mathrm{H}_{2} \mathrm{O}, 1 \mathrm{~g} / 1$ glucose, $10 \mathrm{~g} / \mathrm{l}$ human serum albumin, $\mathrm{pH} 7.3$, for $30 \mathrm{~min}$ before use. The lower compartment of the chambers was filled with $2 \mathrm{ml}$ buffer A alone or with various concentrations of $\mathrm{N}$-formyl-methionylleucyl-phenylalanine in the buffer $A$ to induce chemotaxis. Experiments were started by placing $300 \mu$ l of polymorphonuclear leukocyte suspension in the upper compartment. After $2 \mathrm{~h}$ incubation at $37^{\circ} \mathrm{C}$, (humidity $90 \%, 95 \%$ air, $5 \% \mathrm{CO}_{2}$ ), the remaining supernatant in the upper compartment was collected.

\footnotetext{
1) Enzymes

Human leukocyte elastase Myeloperoxidase
}

Non-adherent cells were removed from the upper filter or the amnion membrane by washing 3 times with $300 \mu l$ of the buffer required for the subsequent enzymatic assay, and combined with the supernatant.

$$
\cdot
$$

\section{Polymorphonuclear leukocyte quantification}

\section{Cell count method}

The polymorphonuclear leukocytes in the filters were fixed with aqueous ethanol (volume fraction 0.7 ) and stained with haematoxylin as described by Boyden (1). The filters were cleared with xylene and placed on a glass slide. Polymorphonuclear leukocytes in each filter were counted in five random, high power fields $(\times 400)$ scanning through the whole depth of the filter. Total polymorphonuclear leukocytes for each filter were calculated from this, and the results expressed as a percentage of the number of cells added to each chamber.

\section{Enzymatic assays}

After collection of the supernatant, the Boyden chambers were dismantled, and each filter or amnion membrane disc was placed in $1 \mathrm{ml}$ of elastase or myeloperoxidase test buffer containing $10 \mathrm{ml} / 1$ Triton X-100 (elastase test buffer: $0.2 \mathrm{~mol} / 1$ triethylamine hydrochloride containing $1.0 \mathrm{~mol} / \mathrm{l} \mathrm{NaCl}$ and $2 \mathrm{~g} / \mathrm{l}$ benzalkonium chloride, $\mathrm{pH} 8.0$; myeloperoxidase test buffer: $83 \mathrm{mmol} / \mathrm{l}$ citric acid, $\left.112 \mathrm{mmol} / 1 \mathrm{Na}_{2} \mathrm{HPO}_{4} \cdot 2 \mathrm{H}_{2} \mathrm{O}, \mathrm{pH} \cdot 5.6\right)$. Cells and granules were disrupted by twofold sonication (Branson cell disrupter, B-15 microtip, step 4 for $10 \mathrm{~s}$, after $20 \mathrm{~min}$ step $5,15 \mathrm{~s})$. The resulting cell lysates were cleared by high speed centrifugation $(15 \mathrm{~min}, 15000 \mathrm{~g}$ ). Elastase activity was assayed at $25^{\circ} \mathrm{C}$ and samples were measured in elastase test buffer using $\mathrm{MeO}$-Suc-Ala-Ala-Pro-Val-4-nitranilide (MeOSuc, methoxysuccinyl) (1 mmol/l dissolved in dimethyl sulphoxide) in a final concentration of $0.05 \mathrm{mmol} / \mathrm{l}$ as substrate (7). For determination of the polymorphonuclear leukocyte mean elastase content $200 \mu \mathrm{l}$ of the cell suspension were centrifuged $(10 \mathrm{~min}, 400 \mathrm{~g})$ and the resulting pellet treated in the same manner as the Boyden chamber samples. The test was standardized with human polymorphonuclear leukocyte elastase (Elastin Products Inc.). To determine spontaneous elastase release during migration, filters were placed in $1 \mathrm{ml}$ of the buffer solution used for resuspending polymorphonuclear leukocytes (see above) and centrifuged at $400 \mathrm{~g}$ for $10 \mathrm{~min}$, and elastase activity in the supernatant was assayed. For measurement of myeloperoxidase activity, samples were incubated at $37^{\circ} \mathrm{C}$ for $45 \mathrm{~min}$ in myeloperoxidase test buffer $(83 \mathrm{mmol} / 1 \mathrm{citric}$ acid, $112 \mathrm{mmol} / \mathrm{l} \mathrm{Na} \mathrm{HPO}_{4} \cdot 2 \mathrm{H}_{2} \mathrm{O}, \mathrm{pH} 5.6$ ) using $0.91 \mathrm{mmol} / \mathrm{l}$ ABTS containing $125 \mu \mathrm{l} / 1 \mathrm{H}_{2} \mathrm{O}_{2}(300 \mathrm{~g} / \mathrm{kg})$ as substrate. Elastase and myeloperoxidase activities were monitored at $405 \mathrm{~nm}$ (Eppendorf photometer).

All assays were carried out in duplicate and intra-assay precisions for all assays were calculated from

$$
\frac{\overline{\mathrm{SD}}}{\overline{\mathrm{x}}} \times 100=\mathrm{CV} \%
$$

$\overline{\mathrm{SD}}$ is the mean of standard deviations for all samples, $\overline{\mathrm{x}}$ is the mean of all samples, and CV is the coefficient of variation.

\section{Results}

\section{. Elastase content of neutrophils}

The total content of polymarphonuclear leukocyte elastase was determined in separate samples after disruption of the polymorphonuclear leukocytes by 
treatment with detergent and a twofold sonication procedure. This procedure ensured the complete release of elastase from the granules. The elastase content was calculated from the determined enzyme activity. The mean protein content was $14.90 \pm 2.7 \mu \mathrm{g}$ elastase for $5 \times 10^{6}$ polymorphonuclear leukocytes ( $n=18,13$ donors). This was comparable to the values reported in literature (8). Therefore, we were able to reliably detect 10000 cells per sample. Spontaneous release of elastase in the supernatant was $<2 \%$, as determined in the supernatant of the samples and the filters after low speed centrifugation.

\section{Comparison of the elastase and cell counting methods}

To compare the elastase and the cell counting methods, two experiments were carried out using parallel methods. The elastase and cell counting method were used to measure the number of cells which migrated in a $5 \mu \mathrm{m}$ filter after chemotactic stimulation. For this purpose, polymorphonuclear leukocyte suspensions (cell count from $1.25 \times 10^{9} / 1$ to $5.0 \times 10^{9} / \mathrm{l}$ ) were placed in the upper compartment and chemotaxis was induced by $10^{7} \mathrm{~mol} / \mathrm{l} \mathrm{N}$-formyl-met-leu-phe in the lower compartment. Under these conditions most of the polymorphonuclear leukocytes migrated into the filter or adhered to the surface. Both methods gave similarly high results (fig. 1), whereby the cell count

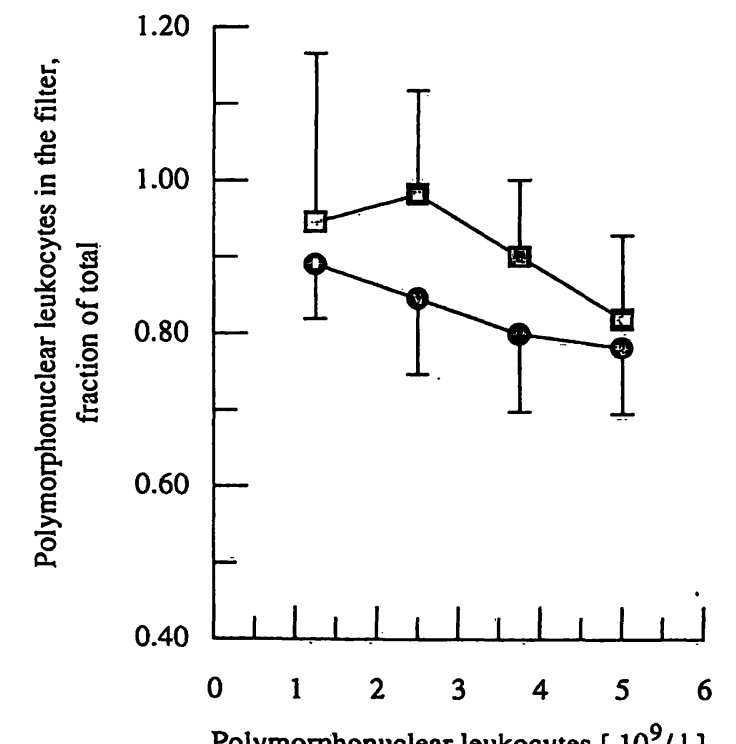

Polymorphonuclear leukocytes [ $\left.10^{9} / 1\right]$

Fig. 1. N-Formyl-met-leu-phe-stimulated polymorphonuclear leukocyte migration into a $5 \mu \mathrm{m}$ Millipore filter at different cell concentrations. Cells were stimulated with $10^{-7} \mathrm{~mol} / 1 \mathrm{~N}$-formyl-met-leu-phe in the lower compartment. Parallel elastase and cell count techniques were employed in each experiment. The number of polymorphonuclear leukocytes in the filter is given as the percentage of total cells in each chamber.

- Elastase method,

- cell count method.

Means $\pm S D$ from 6 experiments. method showed about $8 \%$ more polymorphonuclear leukocytes in the filters (mean for all concentrations), and the mean of standard deviations for all concentrations was $14.2 \%$ for the cell count method and $8.9 \%$ for the elastase method. Higher polymorphonuclear leukocyte concentrations led to a slight decrease in cells in the filter; $+11 \%$ in the elastase method, $+13 \%$ in the cell count method.

Both methods were then tested in a two filter migration assay (fig. 2). A $0.22 \mu \mathrm{m}$ filter was overlayed with an $8 \mu \mathrm{m}$ filter, then chemotactically induced, and spontaneous migration into both filters was measured at two polymorphonuclear leukocyte concentrations. A high percentage of polymorphonuclear leukocytes (up to $78 \%$, elastase method) adhered to the surface or migrated into the upper filter even without stimulation. N-Formyl-met-leu-phe stimulation led to an increase in the polymorphonuclear leukocyte content
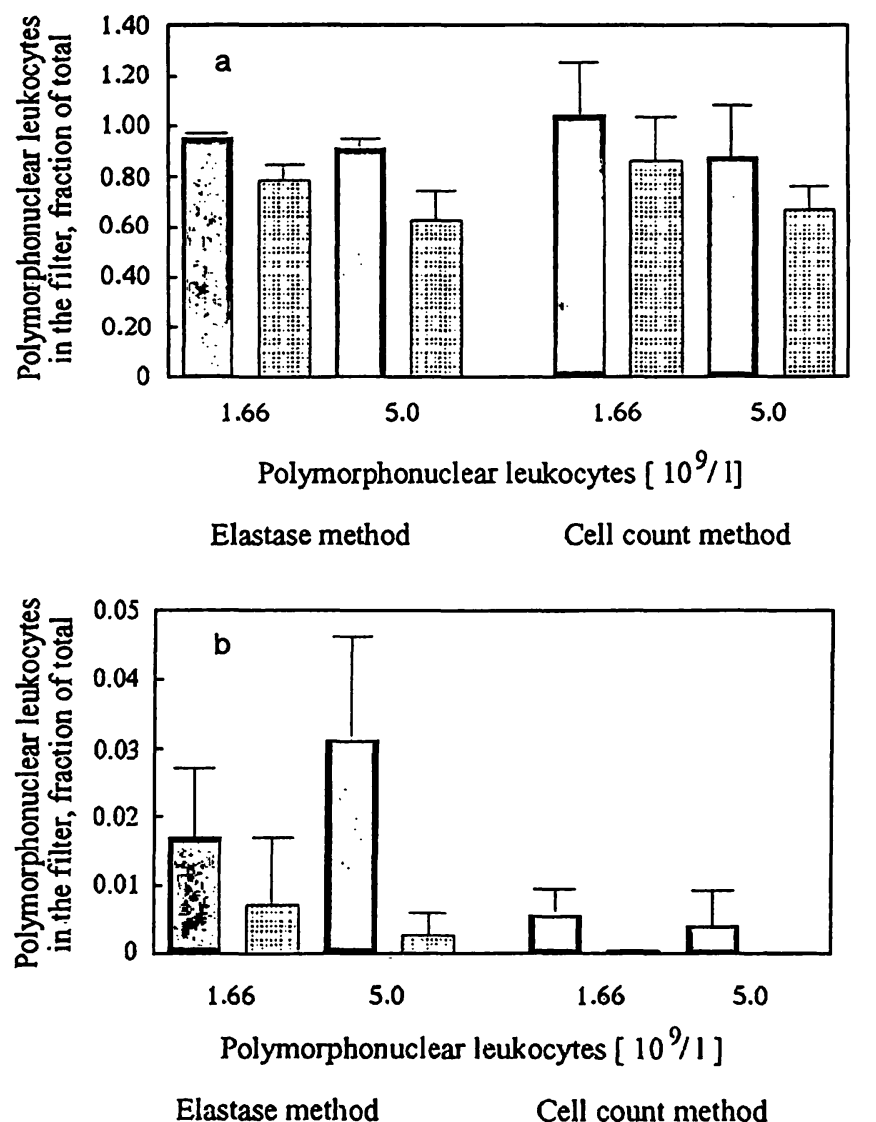

Fig. 2. Unstimulated and N-formyl-met-leu-phe-stimulated polymorphonuclear leukocyte migration measured by the elastase and cell count techniques. Chamber compartments were separated by an upper $8 \mu \mathrm{m}$ and lower $0.22 \mu \mathrm{m}$ Millipore filter; $10^{-7} \mathrm{~mol} / 1 \mathrm{~N}$-formyl-met-leuphe was added to the lower compartment for stimulation. The number of polymorphonuclear leukocytes in the upper (fig. 2a) and the lower filter (fig. 2b) is given as the percentage of total cells in each chamber.

진 $\mathrm{N}$-Formyl-met-leu-phe stimulated polymorphonuclear leukocytes

$\square$ unstimulated polymorphonuclear lcukocytes.

Meäins \pm SD from 8 experiments. 
of the upper filter of up to $95 \%$ (elastase method). A higher cell concentration decreased the percentage of cells in the upper filter without stimulation, but $\mathrm{N}$ formyl-met-leu-phe stimulation diminished this effect. Only a few polymorphonuclear leukocytes were found attached to the lower filter without $\mathrm{N}$-formyl-metleu-phe stimulation. The cell count technique often failed to show any cell in the randomly chosen high power fields. Chemotactic stimulation led to a distinct increase in migration. The elastase method in all cases resulted in higher migration rates into the lower filter. The correlation coefficient between the two methods was $r=0.90$. In all cases the inter-assay standard deviations were higher with the cell count method. The intra-assay precision of the elastase and the cell count method was calculated from both experiments. The coefficients of variation in the upper (only) and lower filter were calculated separately. Results for the elastase method were $6.1 \%(n=14)$ and $24.4 \%$ $(n=8)$, respectively. Results for the cell count method were $12.8 \%(n=14)$ and $30.1 \%(n=8)$, respectively.

\section{Comparison of the elastase and myeloperoxidase methods}

Both methods were applied to a two filter assay with an upper $5 \mu \mathrm{m}$ filter and a lower $0.22 \mu \mathrm{m}$ filter (fig. 3 ). The results of the elastase method for spontaneous and $\mathrm{N}$-formyl-met-leu-phe-stimulated migration into the upper filter were clearly lower $(35.8=-20.5 \%$ and $74.6=-16.6 \%$, respectively), compared with previous results from $8 \mu \mathrm{m}$ filters. Transmigration of polymorphonuclear leukocytes to the lower $0.22 \mu \mathrm{m}$ filter was in accordance with previous results. The results of the myeloperoxidase method and elastase method results correlated with $r=0.94$. Interassay standard deviations for both methods were comparable. The intraassay precision was calculated as above. The coefficients of variation for the elastase method in the upper and lower filter were $6.1 \%$ and $29.4 \%(n=6)$. Results for the myeloperoxidase method were $5.8 \%$ and $25.2 \%(n=6)$.

Application of the elastase method in amnion membrane models

All measurements were carried out using the elastase method. Chemotaxis chambers with a piece of human amnion membrane mounted on a $0.22 \mu \mathrm{m}$ filter were assembled, and $\mathrm{N}$-formyl-met-leu-phe concentrations ranging from $10^{-5} \mathrm{~mol} / \mathrm{l}$ to $10^{-11} \mathrm{~mol} / 1$ (plus controls without chemoattractant) were applied to the lower
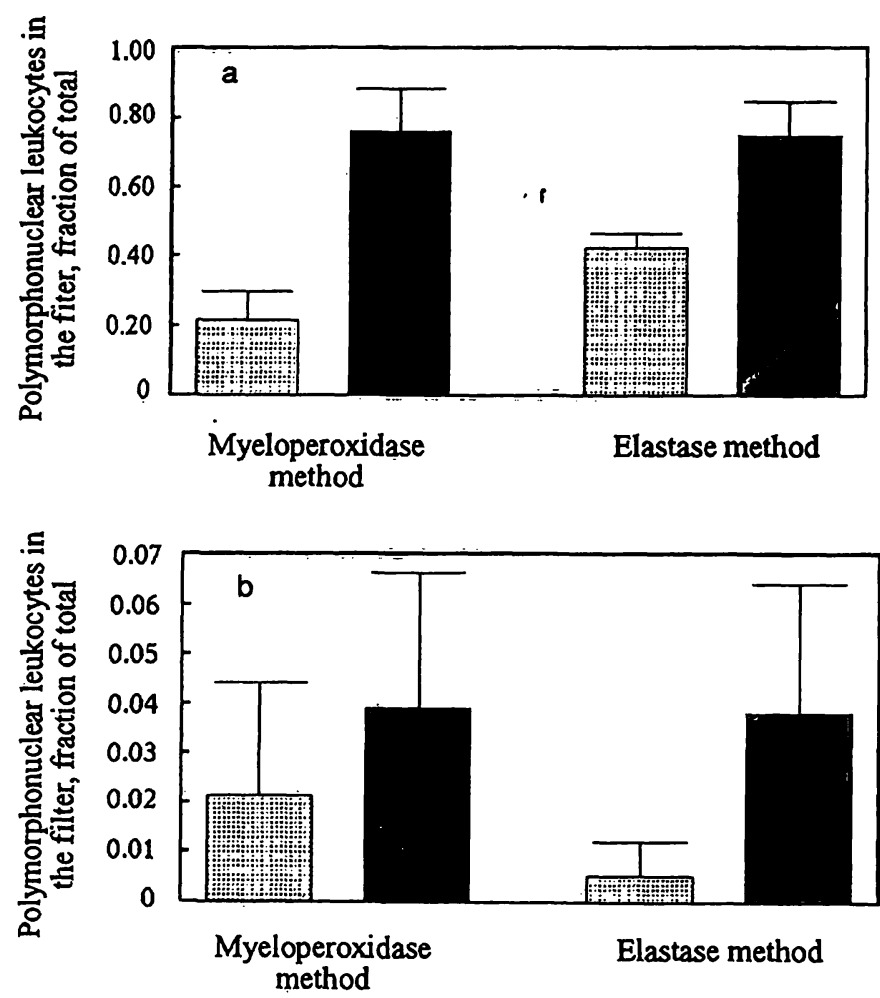

Fig. 3. Unstimulated and N-formyl-met-leu-phe-stimulated polymorphonuclear leukocyte migration measured by the elastase and myeloperoxidase methods. Chamber compartments were separated by an upper $5 \mu \mathrm{m}$ and lower $0.22 \mu \mathrm{m}$ Millipore filter; $10^{-8} \mathrm{~mol} / 1 \mathrm{~N}$-formylmet-leu-phe was added to the lower compartment for stimulation. The number of polymorphonuclear leukocytes in the upper (fig. 3a) and the lower filter (fig. 3b) is given as the percentage of total cells in each chamber. N-Formyl-met-leu-phe stimulated polymorphonuclear leukocytes

을 unstimulated polymorphonuclear leukocytes. Means \pm SD from 6 experiments.

compartment of the chambers. An N-formyl-met-leuphe concentration of $10^{-8} \mathrm{~mol} / \mathrm{l}$ induced maximum adherence to, and migration through the membrane (fig. 4). At higher N-formyl-met-leu-phe concentrations even fewer cells than in unstimulated controls were detected in/on the membrane. Examination of the underlying filter revealed that polymorphonuclear leukocytes migrated through the entire amnion membrane into the filter at only the most stimulatory $\mathrm{N}$ formyl-met-leu-phe concentrations. Even with optimal N-formyl-met-leu-phe stimulation only a small percentage of the cells was detected on the filter: 0.5 $\pm 0.3 \%\left(5 \times 10^{-9} \mathrm{~mol} / \mathrm{l} \mathrm{N}\right.$-formyl-met-leu-phe and $0.5 \pm 0.4 \%\left(1 \times 10^{-8} \mathrm{~mol} / 1 \mathrm{~N}\right.$-formyl-met-leu-phe $)$. Higher or lower $\mathrm{N}$-formyl-met-leu-phe concentrations did not induce any detectable migration into the filter.

A second test showed that variation of the polymorphonuclear leukocyte concentration did not alter the percentage of polymorphonuclear leukocytes found 


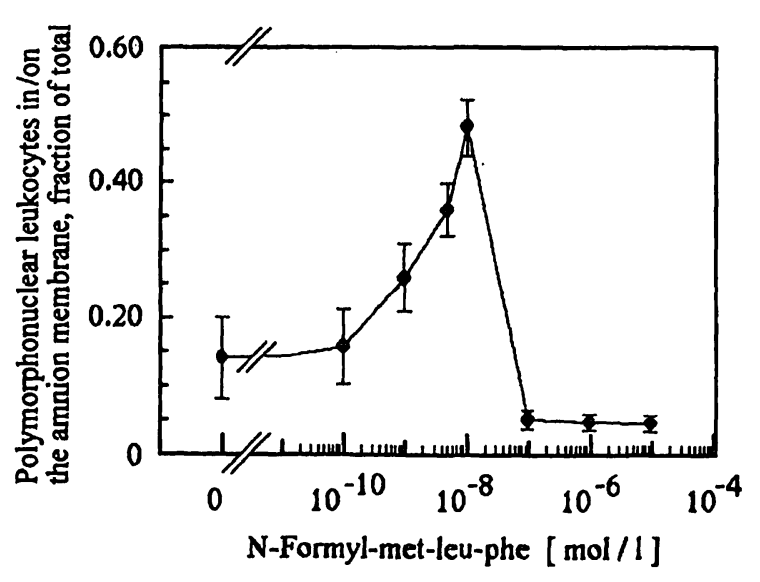

Fig. 4. The effect of $\mathrm{N}$-formyl-met-leu-phe concentration on the polymorphonuclear leukocyte response in chemotaxis chambers equipped with an amnion membrane. The two parts of the chemotaxis chamber were separated by a slice of human amnion membrane on an underlying $0.22 \mu \mathrm{m}$ filter. The polymorphonuclear leukocyte concentration in the upper compartment was $10^{10} / 1$. The results were expressed as the percentage of total polymorphonuclear leukocytes which migrated into, or adhered to the amnion membrane, detected by the elastase method. Means \pm SD from 4 experiments.

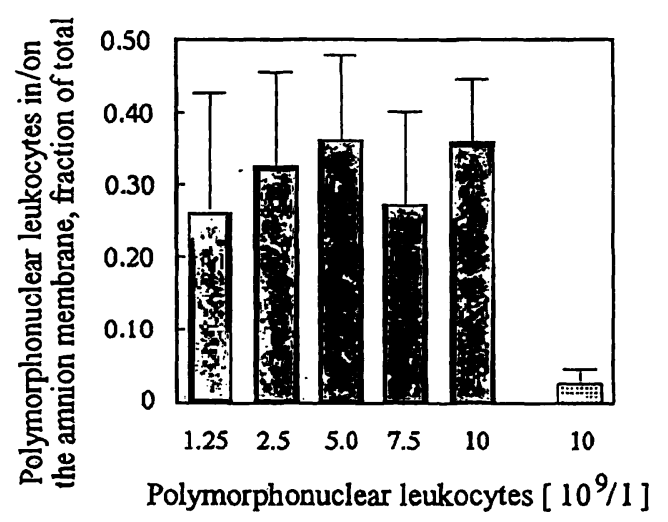

Fig. 5. The effect of polymorphonuclear leukocyte concentration on the neutrophil response in chemotaxis chambers equipped with an amnion membrane, measured by the elastase method. The chemotaxis chambers were separated by a slice of human amnion membrane on an underlying $0.22 \mu \mathrm{m}$ Millipore filter; $10^{-8} \mathrm{~mol} / \mathrm{l} \mathrm{N}$-formyl-met-leu-phe was added to the lower compartment for stimulation. The results show the percentage of cells which migrated into, or adhered to the amnion membrạne.

O N-Formyl-met-leu-phe stimulated polymorphonuclear leukocytes

图 unstimulated polymorphonuclear leukocytes.

Means \pm SD from 6 experiments.

in the amnion membrane after $2 \mathrm{~h}$ of $\mathrm{N}$-formyl-metleu-phe stimulation (fig. 5). This percentage was about 25 to $45 \%$ lower than in similar filter experiments; moreover, in contrast to the filter experiments, unstimulated adherence to or migration of the polymorphonuclear leukocytes into the amnion membrane was minor.

\section{Discussion}

This report describes a new method for assaying polymorphonuclear leukocytes in Boyden chambers operated conventionally or equipped with an amnion membrane. Measurement of elastase activity proved to be a quick and easy method for evaluating Boyden chamber experiments. Human leukocyte elastase is a serine protease primarily associated with polymorphonuclear leukocytes. However, monocytes also con'tain some human leukocyte elastase, and recently Lungarella et al. (9) reported that eosinophils also contain an elastase similar to the major isoenzyme of neutrophil elastase. But the enzyme content of these cell types is reported to be much lower than in neutrophils (the monocyte elastase content is approximately $6 \%$ of that in neutrophils (10)).

As our cell isolation procedure resulted in $99 \%$ polymorphonuclear leukocytes, the elastase content of contaminating cells could be assumed to be extremely low. The enzyme activity measured in our tests therefore derived almost entirely from neutrophils. As recently reported, adherent polymorphonuclear leukocytes release only very little $(<2 \%)$ of their elastase content even after formyl peptide treatment (11). This corresponded with our findings. As a result, the elastase method is not affected by elastase secreted into the medium.

Cell counts and elastase activity in the filters correlated closely in most cases. Although the correlation was adequate, the cell count and elastase results showed systematic differences. Cell counting results in the upper filter were always higher than those calculated from the elastase method. Close examination of the filters revealed that the areal distribution of polymorphonuclear leukocytes was not homogenous. In most cases polymorphonuclear leukocytes were more numerous on the periphery of the filter. Therefore, the results of the cell count method are strongly affected by the distribution of the high power fields on the filter. This effect can hardly be quantified, and any way of choosing the high power fields is more or less arbitrary. In contrast, cell count results for the lower filter led to lower migration rates than elastase activity. We decided to use a fine pore "catcher" filter as recommended by Keller et al. (12) in the lower position. This prevented polymorphonuclear leukocytes from migrating through both filters; they were blocked and remained attached to the surface of the second filter. But, weakly attached cells might have been washed off during the cell count staining procedure and therefore could not be counted. The elastase method avoids this problem. 
Since the results of each elastase test were calculated as a percentage of the total elastase content present in the same test, errors resulting from a different polymorphonuclear leukocyte number in the chambers were also eliminated.

Somersalo et al. (4) presented a modified Boyden chamber assay based on myeloperoxidase. We found that elastase and myeloperoxidase assays gave comparable results, but elastase had some clear advantages in routine use. The enzymatic assays could be carried out at nearly room temperature, and the samples could be stored for up to three days at $4{ }^{\circ} \mathrm{C}$ without much loss of activity. The elastase method may also be a preferable alternative to myeloperoxidase assays when experimental conditions influence the myeloperoxidase measurements.

Russo et al. (6) recommended the use of human amnion membrane for Boy'den chamber investigations. The amnion membrane is a three-layered structure of epithelial cell layer, basement membrane and loose stroma tissue. When the epithelial cell layer is removed the basement membrane appears as a dense collagen network. We found that on this natural matrix barrier most polymorphonuclear leukocytes did not adhere or migrate without further stimulation. N-Formylmet-leu-phe stimulates about $40 \%$ of the cells to migrate into the membrane or adhere to the surface. This percentage was not altered by an 8 -fold rise in cell concentration. Amnion membrane chambers, therefore, permit a sensitive assay widely unaffected by variations in cell concentration. They proved to be well suited for quantifying polymorphonuclear leu- kocyte migration following different types of stimulation. Of course, adherence to, or partial migration into, an amnion membrane cannot be distinguished by the elastase method, but the method provides useful information on leukocyte reactions on a natural basement membrane. However the percentage of polymorphonuclear leukocytes migrating through the whole membrane, even after optimal stimulation, was rather low.

The elastase method provided some advantages over other methods used to evaluate Boyden chamber investigations. It avoids time-consuming and laborious cell labelling with ${ }^{51} \mathrm{Cr}$, which could also lead to prestimulation of the sensitive cells, i.e. the unpolarized polymorphonuclear leukocytes. It is easy to perform without expensive equipment and much less tedious than the cell counting technique. In addition it can provide information on the percentage of cells able to respond to different stimuli and, in the two-filter assay, on the number of cells which migrated through the layer of the upper filter.

Thus, this novel enzymatic approach for measuring granulocyte chemotaxis by quantification of neutrophil elastase provides a simple standard procedure for routine assays.

\section{Acknowledgement}

This work was supported by the Deutsche Forschungsgemeinschaft SFB 223, Project B07. The authors wish to thank the St. Franziskus Hospital, Bielefeld, for supplying amnion membrane and Ms. G. Delany for linguistic advice.

\section{References}

1. Boyden, S. V. (1962) The chemotactic effect of mixtures of antibody and antigen on polymorphonuclear leukocytes. J. Exp. Med. 115, 453-466.

2. Bignold, L. P. (1988) Measurement of chemotaxis of polymorphonuclear leukocytes in vitro: The problems of control of gradients of chemotactic factors, of control of cells and of separation of chemotaxis from chemokinesis [review article]. J. Immunol. Methods 108, 1-18.

3. Gallin, J. E., Clark, R. A. \& Kimball, H. R. (1973) Granulocyte chemotaxis, an improved in vitro employing ${ }^{51}$ Cr.öabelled granulocytes. Immunol. Commun. 1, 421 430.

4. Somersalo, K., Salo, O. P., Björkstén, F. \& Mustakallio, K. K. (1990) A simplified Boyden chamber assay for neutrophil chemotaxis based on quantification of myeloperoxidase. Anal. Biochem. 185, 238-242.

5. Bøyum, A. (1968) Isolation of mononuclear cells and granulocytes from human blood. Scand. J. Clin. Lab. Invest. $21,77-108$.

6. Russo, G. R., Liotta, L. A., Thorgeirsson, U., Brundage, R. \& Schiffmann, E. (1981) Polymorphonuclear leukocyte migration through human amnion membrane. J. Cell. Biol. 91, 459-467.

7. Nakajima, K., Powers, J. C., Asche, B. M. \& Zimmermann, M. (1979) Mapping the extended substrate binding site of cathepsin $G$ and human leukocyte elastase. J. Biol. Chem. $254,4027-4031$.
8. Neumann, S. \& Lang, H. (1989) In: Lehrbuch der Klinischen Chemie und Pathobiochemie (Greiling, H. \& Gressner, A. M., eds.) pp. 1022-1054, Verlag Schattauer.

9. Lungarella, G., Menegazzi, R., Gardi, C., Spessoto, P., De Santi, M. M., Bertoncin, P., Patriarca, P., Calzoni, P. \& Zabucchi, G. (1992) Identification of elastase in human eosinophils, immunolocalization, isolation, and partial characterization. Arch. Biochem. Biophys. 292, 128-135.

10. Campbell, E. J., Silverman, E. K. \& Campbell, M. A. (1989) Elastase and cathepsin $\mathrm{G}$ of human monocytes. J. Immunol. 143, $2961-2968$.

11. Schettler, A., Thorn, H., Jockusch, B. M. \& Tschesche, H. (1991) Release of proteinases from stimulated polymorphonuclear leukocytes. Eur. J. Biochem. 197, 197-202.

12. Keller, H. U., Borel, J. F., Wilkinson, P. C., Hess, M. N. \& Cottier, H. (1972) Re-assessment of Boyden's technique for measuring chemotaxis. J. Immunol." Methods $1,165-$ 168.

Prof. Dr. Harald Tschesche
Universität Bielefeld
Lehrstuhl für Biochemie
Fakultät für Chemie
Postfach 10.0131
D-33501 Bielefeld
Germany

Eur. J. Clin. Chem. Clin. Biochem. / Vol. 31, 1993 / No. 10 